\title{
Portuguese higher education students' adaptation to online teaching and learning in times of the COVID-19 pandemic: personal and contextual factors
}

\author{
Maria Assunção Flores ${ }^{1}$ (D) Alexandra Barros ${ }^{2}$ (D) $\cdot$ Ana Margarida Veiga Simão ${ }^{2}$ (D) \\ Diana Pereira ${ }^{1}$ (D) - Paulo Flores ${ }^{3}$ (D) - Eva Fernandes ${ }^{1}$ (D) - Luís Costa ${ }^{1}$ (D) \\ Paula Costa Ferreira ${ }^{2}$ (D)
}

Accepted: 30 July 2021 /Published online: 3 September 2021

(C) The Author(s), under exclusive licence to Springer Nature B.V. 2021

\begin{abstract}
The COVID-19 pandemic brought about a global crisis affecting all sectors of society. Higher education is no exception. The closure of higher education institutions has dictated a sudden and unexpected transition from face-to-face to remote teaching to mitigate the spread of the SARS-CoV-2. This paper draws upon a wider piece of research which aimed to understand how higher education students adapted to the closure of their institution and how they looked at their experience of online teaching and learning. In total, 2718 students from different Portuguese higher education institutions participated in the study. Findings showed that both personal and contextual factors explained students' positive or negative adaptation to online teaching and learning as a result of the closure of higher education institutions. Institutional and pedagogical responses, individual selfregulatory and socio-emotional competencies and adequate resources were factors that led to either a more positive or negative student experience of online teaching and learning in times of COVID-19.
\end{abstract}

Keywords Higher education · COVID-19 · Online teaching and learning $\cdot$ Students $\cdot$ Adaptation process

\section{Introduction}

The COVID-19 pandemic brought about a global crisis affecting all sectors of society. Higher education is no exception. The transition from face-to-face to online teaching was sudden and unexpected. It entailed both challenges and opportunities to rethink teaching and learning in

Maria Assunção Flores

aflores@ie.uminho.pt

Extended author information available on the last page of the article 
different environments. In other words, "while this is a strong stress test for education systems, this is also an opportunity to develop alternative education opportunities" (OECD, 2020, p.1).

The forced and unprecedented shift to online teaching is seen as a turning point to change education (and higher education in particular) and to promote innovation, but issues of equity and social justice also need to be included into the equation (Flores \& Gago, 2020), as well as teachers' and institutions' predispositions and conditions for operating in different teaching and learning environments. A recent study carried out in the Portuguese context showed that the main constraints to digital innovation in higher education institutions are associated with limited infrastructure and resources, lack of funding opportunities, insufficient technological resources, a conservative academic culture and lack of technical support (Vicente et al., 2020).

Other studies carried out in Portugal also revealed that students presented some concerns regarding not being able to successfully complete the academic year, the stress caused by the change in teaching methods (Xavier et al., 2020) and the lack of face-to-face practical and laboratory classes (Gonçalves et al., 2020). These and other issues, particularly both the processes of personal and institutional adaptation to online teaching and learning, need to be taken into consideration to fully understand their effects on teaching and learning.

On March 13, 2020, the Portuguese Ministry of Science, Technology and Higher Education announced the closure of all higher education institutions to mitigate the spread of the SARSCoV-2. All activities which included the presence of students were suspended on March 16. Furthermore, the same communication stipulated that "efforts should be done to promote online teaching and learning, keeping the activities through teacher and student interaction via digital tools" (MCTES, 2020, p. 1).

It is, therefore, important to investigate how the transition to online teaching and learning was experienced by the higher education students, including the conditions for its implementation and opportunities to learn. To our knowledge, there is a scarcity of empirical studies published so far in the Portuguese context. This study may inform future research intended to investigate this topic not only in the Portuguese context, but in other jurisdictions as well. This paper draws upon a wider piece of research which aims to understand how higher education students perceived their online teaching and learning experience and adapted to the closure of their institution. In particular, the following research questions are addressed:

Are there any differences regarding experiences of online teaching and learning during lockdown and the adaptation to one's own learning process between students who had previous experience of online teaching and those who had not?

Are there any differences regarding perceptions about online teaching, the adaptation to the learning process, the difficulties encountered and the practices and motivations of teachers between students who had a positive adaptation to the closure of their institution and those who had not?

What types of contextual factors are more associated with a positive adaptation to learning and teaching online?

What are the indicators of adaptation to online teaching and learning of students who preferred online teaching, face-to-face teaching or blended learning for the next academic year?

Are there any differences between male and female students regarding their adaptation to the learning process and assessment?

What are students' perceptions regarding online assessment and how did they adapt to it?

Do students' perceptions about online assessment differ depending on whether assessment was synchronous or asynchronous? 


\section{Literature review}

\section{The forced transition from face-to-face to remote teaching in higher education}

Recent literature has focused on how institutions and programmes adapted to online teaching and learning (Bao, 2020; Flores \& Gago, 2020; Quezada et al., 2020; Zhang et al., 2020) and on how students experienced it considering specific aspects of this type of method (Demuyakor, 2020).

In Ireland, Hill and Fitzgerald (2020) found that online experience entailed many challenges that may have resulted in students' reduced engagement and disrupted learning opportunities. The authors identified positive aspects regarding online learning experiences, including flexibility of learning, such as performing activities at students' pace and being able to learn at a location which was convenient for students. They also suggested that a hybrid approach could be positive in the future with increased staff and student engagement through interactive activities.

A study carried out at a dental school in the USA also showed that students had a strong preference for synchronous recorded live lectures and asynchronous pre-recorded lectures with synchronous follow-up sessions, compared to nonrecorded live lectures. The same study found that students felt that learning formats like flipped classrooms and creative uses of technology would be beneficial to their virtual learning (Chen et al., 2020).

Another study carried out in Germany showed that students' readiness for digital learning and their self-reported socio-emotions were correlated. Students who claimed to be ready for digital learning reported less tension, overload, worries and social and emotional loneliness and more joy than those who did not (Händel et al., 2020).

Son et al. (2020) conducted interview surveys at a large university in the USA and found that most students indicated increased stress and anxiety due to the COVID-19 outbreak, fear and concern about their own and their loved ones' health, difficulty in concentrating, disruptions to sleeping patterns, decreased social interactions due to physical distancing and increased concerns on academic performance.

Despite all the challenges and difficulties encountered by the students in remote education, a study carried out at a medical school in China found that prior learning experiences were positively associated with students' evaluation of and satisfaction with current online education (Wang et al., 2020).

Similarly, research carried out in Saudi Arabia points to positive aspects, namely faculty and students' acceptance of online education, and also to a number of challenges, namely issues related to communication, assessment, the use of technological tools and anxiety and stress (Rajab et al., 2020). Also, Osman (2020) analysed the impact of the COVID-19 pandemic on students from a university in the Sultanate of Oman and found that most were pleased with their online experience and achievement of course objectives. They were satisfied with the type and level of online interaction with their teachers and with the quality and clarity of the recorded lectures, teaching methods and e-learning material.

In Spain, Gonzalez et al. (2020) found that there was a significant positive effect of the COVID-19 lockdown on students' performance. The authors concluded that such an effect was significant both in subjects that increased the number of assessment activities and in subjects that did not change the student workload. They also suggest that COVID-19 lockdown changed students' learning strategies towards a more continuous manner. 
A large-scale study aimed at analysing the impact of the first wave of COVID-19 concluded that most of the students were satisfied with the support provided by teachers and by their university (Aristovnik et al., 2020). Despite this, students highlighted some difficulties, such as the lack of computer skills and higher workload that may have hindered them from perceiving their improved performance in this new teaching environment, as well as concern with their future professional career and negative feelings, such as boredom, anxiety and frustration. Gender differences were also found as male students assessed their confidence in computer skills higher than female students. This study also showed that sociodemographic factors appeared as important predictors of satisfaction with and perception of specific segments as, in general, female, full-time students, studying at the second level, studying social sciences, having a scholarship, without financial problems and not losing a students' job due to the COVID-19 pandemic, appeared to be more satisfied and assessed the studied elements in a more positive way (Aristovnik et al., 2020).

In a similar vein, the study by Bisht et al. (2020) found that gender had a significant role in adopting online education by stressing that female students adopted online education more in terms of assignments, study patterns and comfort than males. Alves et al. (2020) also concluded that female students presented higher levels of knowledge, more positive attitudes and engaged in more preventive behaviours than male students regarding COVID-19 pandemic. Moreover, Shahzad et al. (2020) also found differences between male and female students' accessibility to their e-learning portals. The authors found that E-learning portal usage is more towards female students in Malaysian Universities.

\section{Remote assessment in higher education}

The move towards online environments entailed a number of challenges and some disruption at different levels (Metcalfe, 2020; Yang, 2020), namely in terms of remote teaching and assessment. For instance, academic dishonesty has been identified by far as the most frequently discussed challenge in higher education, since the capacity to control students' actions is reduced (Guangul et al., 2020; OECD, 2020). Thus, students achieving higher scores in remote assessment could be linked to cheating in online assessments, whereas lower grades could also be caused by the assessment format change or be attributable to autonomous learning as a less effective teaching method (Gonzalez et al., 2020). A study by Guangul et al. (2020) concluded that personalised questions, online presentations, as well as the combination of various assessment methods were seen by students as a good option to control academic integrity violations. Beyond academic dishonesty, other challenges and limitations have been identified in the literature, such as the lack of resources and infrastructures, the coverage of learning outcomes, the commitment of students to submit assessments (Guangul et al., 2020), the difficulty in assessing practical knowledge and skills, the need to ensure a fair treatment of test takers and the risk of technical failure (OECD, 2020).

The issue of equity, as one of the main concerns in remote assessment, should be considered since "assessments risk introducing error due to non-cognitive issues, and an attainment gap" (Fuller et al., 2020, p. 783). Despite these constraints, there is a range of tools available to face the challenges of remote assessment imposed by the COVID-19 pandemic. Guangul et al. (2020) classified remote assessments as (1) remotely proctored exams (time-constrained and commonly used in the classrooms, but may present several drawbacks) and (2) open-ended assessments. Studies have suggested that students preferred to perform assessments in a long span of time rather than in a short span of time (Guangul 
et al., 2020). In order to redesign assessment in this context, other assessment methods have been identified in the literature such as quizzes, take-home assessments, demonstrations, oral presentations, fact sheets, e-portfolios (Guangul et al., 2020), argumentative essays, synthesis papers, critical analysis, blog posts, student diaries, discussions on blogs, wikis or forums, research projects and student presentations of the outcomes of asynchronous assignments (synchronously in front of the class or asynchronously through podcasts, video recordings or any other types of multimedia product) (OECD, 2020) and well-designed open-book tests using questions that are not easily answerable by an Internet search engine (Fuller et al., 2020).

The literature suggests the use of continuous assessment (García-Peñalvo et al., 2020), as it can work as a tool to keep engagement (Levatti, 2020). Recent studies found that students in a computer-based testing environment reported lower levels of negative emotions than their typical negative test emotions (Harley et al., 2020). Moreover, the lockdown experience improved students' performance and test scores, even in tests that were performed in the online format in previous years - an improvement which was attributed to new learning methodologies (Gonzalez et al., 2020). According to Fuller et al. (2020, p. 782), "all will have faced wider personal disruption - and so it is essential that changes to assessment are accompanied by a review of rules and processes (e.g. around mitigation, appeals and the number of permitted attempts)". Furthermore, institutions must provide digital support without compromising academic quality and curriculum standards (Crawford et al., 2020).

Brady and Pradhan (2020) also suggested that techniques of distance learning may prove beneficial for continuation after the pandemic has passed. The authors stressed that in the transition to a distance learning curriculum, teachers should use active learning techniques rather than passive methods and should foster interaction as much as possible when synchronous techniques are used. Similarly, Osman (2020) noted that it was important to reflect on the assessment of students' performance in online environments, particularly concerning practical skills, technical competencies and teaching practicum; to look at faculty training in instructional design; and issues of students' equal access to e-learning environments.

\section{Methods}

\section{The present study}

In general, existing research literature focusing on students' experience of online teaching in times of COVID-19 pandemic has shown positive features, for instance their readiness for digital learning, but also issues that deserve further consideration, such as assessment in online environments, as well as internal and external factors affecting students' predispositions for online learning. This paper draws upon a wider piece of research aimed at investigating higher education students' perceptions and experiences of online teaching and learning during lockdown, including their adaptation to the closure of their institution.

\section{Instrument}

A questionnaire based on a previous study of the experience of teachers in remote teaching, resulting from both legal and theoretical frameworks related to teaching and assessment, was designed (Flores et al., 2021). It included both open- and closed-ended questions which were 
organised in three sections, in addition to the students' biographical data: (1) perceptions and experiences concerning the conditions for online teaching and learning; (2) perceptions and experiences concerning the process of online teaching and learning; and (3) perceptions and experiences concerning assessment and feedback. The first section included items related to resources and equipment for online teaching and learning (e.g. Do you own a laptop for online teaching?); problems encountered (e.g. time management, task management); online tools used to facilitate online teaching and learning (e.g. online platforms, email); and the adaptation process to the closure of the institution (e.g. I am dealing well with online teaching and learning; I feel tired with online teaching and learning). The second section included items related to students' perceptions and experiences of online teaching and learning (e.g. I find it easy to follow my daily routine of online teaching; I learn well through online teaching); strategies and tools recommended and not recommended (open-ended question); and preferable format of teaching in the future (only face-to-face teaching, only online teaching or both). The third section consisted of a set of items related to perceptions about online assessment in terms of learning and effectiveness (e.g. Assessment is more effective online than in face-toface teaching); most used methods of assessment (from a list of methods, such as portfolios, written tests, oral tests); and feedback received. The questionnaire also included a number of open-ended questions to get first-hand descriptions of online tools and strategies. In this paper, items related to students' perceptions and experiences of online teaching and learning, as well as assessment, will be described.

\section{Participants}

The sample consisted of 2718 students from different cycles of study (graduate degree, master's degree, $\mathrm{PhD}$ ), although 1183 opted not to respond to the biographical data questions. Table 1 shows students who filled in all of the questions, including biographical data. Most were undergraduate students $(46.5 \%)$, but integrated master's degree students (38.6\%), academic master's degree students (8.3\%) and professional master's degree students (3.5\%) also participated. Only $2.1 \%$ attended $\mathrm{PhD}$ programmes. Students attended the 1 st $(36.8 \%)$, 2nd $(26.6 \%)$ and 3rd (23.1\%) years mainly. Most participants were female (65.8\%) and younger than 25 years old. Only $8.8 \%$ of the participants were more than 30 years old. The students were enrolled in programmes in different fields of knowledge, most of whom were doing Engineering, Educational Sciences, Medicine, Psychology and Law.

\section{Data collection procedures}

A link to the survey was created through Qualtrics and sent out to the students via students' unions. Students from all areas of knowledge (e.g. Social Sciences, Engineering and Technology, Health Sciences) and cycles of study (e.g. undergraduate, masters and $\mathrm{PhD}$ ) were invited. The questionnaire was administered between June 12 and August 12, 2020. A nonprobability convenience sample was used.

\section{Ethical issues}

The research project was carried out according to international educational research ethics, namely data confidentiality, informed consent, voluntary participation and the use of the data collected only for research purposes. The project was approved by the Ethics Committee for 
Table 1 Demographic characteristics of the participants

f $\%$

$\begin{array}{lcc}\text { Gender } & & \\ \text { Male } & 525 & 34.2 \\ \text { Female } & 1010 & 65.8 \\ \text { Age } & & 24.6 \\ \text { More than 20 years old } & 378 & 59.6 \\ 20 \text { - 25 years old } & 915 & 7.0 \\ 26 \text { - 30 years old } & 107 & 2.6 \\ 31 \text { - 35 years old } & 40 & 2.3 \\ 36 \text { - 40 years old } & 35 & 3.9 \\ \text { More than 40 years old } & 60 & 46.5 \\ \text { Cycle of study } & & 38.6 \\ \text { Graduate Degree } & 714 & 3.5 \\ \text { Integrated Masters' Degree } & 592 & 8.3 \\ \text { Professional Masters' Degree } & 54 & 0.9 \\ \text { Academic Masters' Degree } & 128 & 2.1 \\ \text { Specialisation Course } & 14 & 36.8 \\ \text { PhD } & 33 & 26.6 \\ \text { Academic year } & & 23.1 \\ 1 & 565 & 9.1 \\ 2 & 409 & 3.9 \\ 3 & 355 & 0.4 \\ 5 & 140 & 60 \\ 6 & 6 & \end{array}$

Research in Social and Human Sciences at the University of Minho (Ref ${ }^{a}$. CEICSH 057/2020). Participants were informed about the goals of the project prior to giving their consent. The link to complete the questionnaire and the research protocol was sent to all participants all of whom confirmed their voluntary informed consent to participate in the study.

\section{Data analysis}

Data were analysed through IBM SPSS Statistics version 25. Descriptive statistics and correlations between variables were computed to answer the research questions of this study. The means of different groups were compared with t-tests for equality of means of independent samples and one-way ANOVAs followed by post-hoc Tukey tests.

\section{Results}

\section{Differences in students' adaptation to and experience of online teaching and learning between those who had previous experience of online teaching and those who had not}

Through t-test for equality of means of independent samples, significant differences $(p<0.0001)$ were found when comparing the perceptions about how students experienced online teaching between those who had prior experience with online teaching and learning and those who had not had this kind of experience. Students who had previous experience of 
online teaching and learning had higher means in all items related to a positive adaptation. Specifically, they were dealing well with online teaching and learning, were motivated and satisfied, felt comfortable with online teaching and learning and claimed that they learned well through online teaching. In contrast, students without prior experience of online teaching and learning showed fear/anxiety, tiredness and stress. These students also had higher means in the items related to difficulties in concentrating and in resisting external difficulties. Results revealed that students without any experience considered online teaching and learning more difficult, whereas those with experience found it more dynamic and effective than face-to-face teaching (Table 2).

\section{Differences in students' perceptions about online teaching and learning between those who had a positive adaptation to the closure of their institution and those who had not}

Results related to the ways in which students adapted to the closure of their institution showed that $37.5 \%$ claimed they adapted well, $38.6 \%$ had a negative experience and $23.9 \%$ were neutral (they did not have either a positive or a negative experience). To analyse the factors associated with the success of the process of adaptation, a t-test for equality of means of independent samples was carried out to compare the perceptions

Table 2 Perceptions about online teaching and learning: t-test for equality of means of independent samples by previous experience

\begin{tabular}{|c|c|c|c|}
\hline & $\begin{array}{l}\text { Without } \\
\text { Experience } \\
M(S D)\end{array}$ & $\begin{array}{l}\text { With } \\
\text { Experience } \\
M(S D)\end{array}$ & $\begin{array}{l}t \\
(d . f .)\end{array}$ \\
\hline I am dealing well with online teaching and learning. & $2.73(1.24)$ & $3.27(1.38)$ & $\begin{array}{l}-4.17 * * \\
(135.48)\end{array}$ \\
\hline I feel motivated with online teaching and learning. & $2.19(1.17)$ & $2.86(1.42)$ & $\begin{array}{c}-5.16^{* *} \\
(133.55)\end{array}$ \\
\hline I feel comfortable with online teaching and learning. & $2.50(1.17)$ & $3.24(1.36)$ & $\begin{array}{l}-5.85 * * \\
(134.45)\end{array}$ \\
\hline I learn well through online teaching. & $2.76(1.19)$ & $3.29(1.28)$ & $\begin{array}{c}-4.60 * * \\
(1756)\end{array}$ \\
\hline I feel satisfied with online teaching. & $2.45(1.23)$ & $3.02(1.36)$ & $\begin{array}{l}-4.73 * * \\
(1756)\end{array}$ \\
\hline I feel tired with online teaching and learning. & $4.05(1.1)$ & $3.51(1.34)$ & $\begin{array}{l}5.18^{* *} \\
(133.16)\end{array}$ \\
\hline I feel stressed with online teaching and learning. & $3.95(1.15)$ & $3.20(1.40)$ & $\begin{array}{c}5.80 * * \\
(133.24)\end{array}$ \\
\hline I feel fear in relation to online teaching and learning. & $3.76(1.18)$ & $3.08(1.51)$ & $\begin{array}{c}4.87 * * \\
(132.18)\end{array}$ \\
\hline I feel that I learn more now than in face-to-face teaching. & $2.09(1.11)$ & $2.60(1.29)$ & $\begin{array}{l}-4.10 * * \\
(126.06)\end{array}$ \\
\hline I have difficulties in concentrating with online teaching. & $3.80(1.18)$ & $3.28(1.45)$ & $\begin{array}{c}3.76^{* *} \\
(124.64)\end{array}$ \\
\hline $\begin{array}{l}\text { It is difficult to follow online teaching at home because there are } \\
\text { external distractions. }\end{array}$ & $3.41(1.28)$ & $3.03(1.50)$ & $\begin{array}{c}2.60 * * \\
(125.89)\end{array}$ \\
\hline Online teaching is more dynamic than face-to-face teaching. & $1.88(0.98)$ & $2.36(1.22)$ & $\begin{array}{l}-4.09 * * \\
(124.70)\end{array}$ \\
\hline
\end{tabular}

\footnotetext{
** Significant at $p<0.0001$
} 
about online teaching and learning of students with a negative or positive adaptation to the closure of their university (Table 3 ). Results revealed that students who adapted negatively to the closure of their university reported lack of support from their teachers and their institution and lack of adequate equipment. They also showed higher means $(p<0.001)$ in items related to difficulties in concentrating, time management, responding to teachers' assignments and complying with all the tasks required of them, including following online teaching. On the contrary, students who adapted well had higher means in the items related to dealing well with online teaching and learning, not having difficulties in following online teaching and their daily routine, being comfortable and motivated in online teaching and found online teaching more dynamic than face-to-face teaching. They also revealed higher means in items related to their perceptions about teachers being available and providing them with material and extra explanations of the topics. In addition, students

Table 3 Students' perceptions about online teaching and learning: t-test for equality of means of independent samples by adaptation to the closure of the institution

\begin{tabular}{|c|c|c|c|}
\hline & $\begin{array}{l}\text { Negative } \\
\text { adaptation } \\
M(S D)\end{array}$ & $\begin{array}{l}\text { Positive } \\
\text { adaptation } \\
M(S D)\end{array}$ & $\begin{array}{l}t \\
(d . f .)\end{array}$ \\
\hline I am dealing well with online teaching and learning. & $1.83(0.88)$ & $\begin{array}{l}3.76 \\
(0.10)\end{array}$ & $\begin{array}{l}-39.70 * * \\
(1459.21)\end{array}$ \\
\hline I feel motivated with online teaching and learning. & $1.45(0.69)$ & $\begin{array}{l}3.12 \\
(1.20)\end{array}$ & $\begin{array}{l}-32.80 * * \\
(1170.35)\end{array}$ \\
\hline For me it is easy to follow the online teaching routine. & $2.33(1.23)$ & $\begin{array}{l}3.52 \\
(1.16)\end{array}$ & $\begin{array}{c}-18.61 * * \\
(1412)\end{array}$ \\
\hline I feel comfortable with online teaching and learning. & $1.77(0.87)$ & $\begin{array}{l}3.39 \\
(1.1)\end{array}$ & $\begin{array}{l}-31.74 * * \\
(1404.32)\end{array}$ \\
\hline I feel satisfied with online teaching. & $1.61(0.81)$ & $\begin{array}{l}3.45 \\
(1.07)\end{array}$ & $\begin{array}{l}-36.44 * * \\
(1292.38)\end{array}$ \\
\hline I have access to the resources that I need for online teaching and learning. & $3.21(1.23)$ & $\begin{array}{l}4.09 \\
(0.96)\end{array}$ & $\begin{array}{l}-15.38 * * \\
(1426.16)\end{array}$ \\
\hline I feel tired with online teaching and learning. & $4.49(0.81)$ & $\begin{array}{l}3.43 \\
(1.26)\end{array}$ & $\begin{array}{l}19.16^{* *} \\
(1256.5)\end{array}$ \\
\hline I feel stressed with online teaching and learning. & $4.45(0.85)$ & $\begin{array}{l}3.23 \\
(1.29)\end{array}$ & $\begin{array}{c}21.61 * * \\
(1271.73)\end{array}$ \\
\hline I feel fear in relation to online teaching and learning. & $4.32(0.90)$ & $\begin{array}{l}2.99 \\
(1.27)\end{array}$ & $\begin{array}{c}23.47 * * \\
(1322.96)\end{array}$ \\
\hline I have difficulties in concentrating with online teaching. & $4.31(0.92)$ & $\begin{array}{l}3.12 \\
(1.25)\end{array}$ & $\begin{array}{c}20.25^{* *} * \\
(1275.25)\end{array}$ \\
\hline $\begin{array}{l}\text { I find it difficult to follow online teaching at home because there are } \\
\text { external distractions. }\end{array}$ & $3.98(1.06)$ & $\begin{array}{l}2.71 \\
(1.28)\end{array}$ & $\begin{array}{c}20.22 * * \\
(1348.73)\end{array}$ \\
\hline My teachers know how to teach online teaching. & $2.37(1.0)$ & $\begin{array}{l}3.30 \\
(1.05)\end{array}$ & $\begin{array}{c}17.04 * * \\
(1412)\end{array}$ \\
\hline My teachers are motivated for online. & $2.19(0.92)$ & $\begin{array}{l}3.00 \\
(1.06)\end{array}$ & $\begin{array}{c}-15.43 * * \\
(1367.52)\end{array}$ \\
\hline I am able to interact with my teachers whenever I need to. & $2.72(1.14)$ & $\begin{array}{l}3.68 \\
(1.05)\end{array}$ & $\begin{array}{c}-16.45 * * \\
(1409.41)\end{array}$ \\
\hline $\begin{array}{l}\text { My teachers provide me with material and extra explanations through a } \\
\text { variety of means (audio presentations, images, ppt., etc.) }\end{array}$ & $3.34(1.06)$ & $\begin{array}{l}3.86 \\
(0.96)\end{array}$ & $\begin{array}{l}-9.70 * * \\
(1405.51)\end{array}$ \\
\hline Online teaching is more dynamic than face-to-face teaching. & $1.54(0.79)$ & $\begin{array}{l}2.37 \\
(.1)\end{array}$ & $\begin{array}{l}-16.28 * * \\
(1256.16)\end{array}$ \\
\hline
\end{tabular}

$* *$ Significant at $p<0.0001$ 
Table 4 Correlations between a positive adaptation to online teaching and learning and contextual factors

\begin{tabular}{|c|c|c|c|c|c|}
\hline & $\begin{array}{l}\text { Lack of } \\
\text { support } \\
\text { from } \\
\text { teachers }\end{array}$ & $\begin{array}{l}\text { Having the adequate } \\
\text { conditions for online } \\
\text { teaching and learning }\end{array}$ & $\begin{array}{l}\text { I am able to interact } \\
\text { with my teachers } \\
\text { whenever I need. }\end{array}$ & $\begin{array}{l}\text { My teachers } \\
\text { provide me } \\
\text { with material. }\end{array}$ & $\begin{array}{l}\text { I } \\
\text { received } \\
\text { feedback. }\end{array}$ \\
\hline $\begin{array}{l}\text { Positive adaptation } \\
\text { to the closure of } \\
\text { the institution }\end{array}$ & $-.34 * *$ & $-.18 * *$ & $.39 * *$ & $.26^{* *}$ & $.24 * *$ \\
\hline $\begin{array}{l}\text { Positive evaluation } \\
\text { of online } \\
\text { teaching and } \\
\text { learning }\end{array}$ & $-.45^{* *}$ & $-.21 * *$ & $.46^{* *}$ & $.36^{* *}$ & $.36^{* * *}$ \\
\hline $\begin{array}{l}\text { Dealing well with } \\
\text { online teaching } \\
\text { and learning }\end{array}$ & $-.39 * *$ & $-.24 * *$ & $.41 * *$ & $.29 * *$ & $.28 * *$ \\
\hline $\begin{array}{l}\text { Learning well with } \\
\text { online teaching } \\
\text { and learning }\end{array}$ & $-.43 * *$ & $-.19 * *$ & $.47 * *$ & $.37 * *$ & $.34 * *$ \\
\hline
\end{tabular}

**Significant at $p<0.01$

who adapted well showed significantly lower means in items related to negative emotions, such as stress and tiredness.

\section{Factors associated with the adaptation to the closure of the institution}

Non-parametric correlations (Table 4) between criteria related to a positive adaptation and contextual factors showed that higher positive correlations were found when the possibility to interact with the teachers existed. Negative correlations, on the contrary, were associated with the lack of support from teachers. This finding highlights the key role of teachers in the adaptation process to online teaching and learning.

When considering the perceptions of students who were successful in their learning process, the item with higher correlations was the lack of support from teachers (inverse correlation) and their availability (positive correlation). The item with lower correlation with adaptation and success in the learning process was associated with external conditions. Feedback also showed high correlations with both the indicators of a positive adaptation and success in the learning process.

\section{Adaptation to online teaching and learning and the most preferred format of teaching in the future}

Most students who claimed to have adapted negatively to the experience of online teaching mentioned that they would prefer only face-to-face teaching in the next academic year. However, most students who adapted positively referred that they would prefer a hybrid format (68\%). A large percentage of students who adapted negatively $(42 \%)$ would also prefer both face-to-face and online teaching (Table 5).

With a one-way ANOVA, followed by a post-hoc Tukey test (Tables 6 and 7), means obtained in the indicators of positive and negative adaptation to online teaching and learning were compared between students who mentioned they would prefer face- 
Table 5 Students' preferences of teaching formats for the next academic year depending on their adaptation process

Students who adapted negatively to Students who adapted positively to online teaching and learning online teaching and learning Valid percentage $\quad$ Valid percentage

\begin{tabular}{lcc}
$\begin{array}{l}\text { I would prefer only online teaching } \\
\text { and learning }\end{array}$ & 1.8 & 14.8 \\
$\begin{array}{l}\text { I would prefer only face-to-face } \\
\text { teaching and learning }\end{array}$ & 56.2 & 17.2 \\
$\begin{array}{l}\text { I would prefer both face-to-face and } \\
\text { online teaching and learning }\end{array}$ & 42 & 68 \\
\hline
\end{tabular}

to-face, online and a hybrid format for the next academic year. Results indicated that students who preferred only online teaching had significantly higher means than those who preferred both formats of teaching and only face-to-face teaching $(p<0.01)$ in all positive indicators. Students claimed that they learned well through online teaching, adapted positively to the closure of their institution, felt comfortable, dealt well with online teaching and evaluated their online experience positively. Regarding the negative indicators, students who indicated they would prefer the face-to-face format had higher means in feelings of fear, tiredness and stress related to online teaching.

\section{Gender differences in students' adaptation to online teaching and assessment}

In relation to students' perceptions about online teaching, no significant differences were found between male and female students (Table 8). A t-test for equality of means of independent samples was also carried out to compare students' perceptions about online teaching. Female students revealed significantly higher means in the item related to stress. Nevertheless, despite the difficulties, female students showed higher means in the items related to satisfaction, adaptation and perception of academic success.

No statistically significant differences were found between male and female students in relation to assessment. Only male students considered online assessment more unfair than face-to-face assessment and were also less satisfied with online assessment $(p<0.05)$.

Table 6 One-way ANOVA: differences in adaptation to online teaching by preferred format of teaching

\begin{tabular}{lc}
\hline & $\mathrm{F}(2 \mathrm{~d} . f)$. \\
\hline I learn well with online teaching and learning. & $249.005^{* *}$ \\
I adapted positively to the closure of the institution. & $198.18^{* *}$ \\
I feel comfortable with online teaching and learning & $249.49^{* *}$ \\
I am dealing well with online teaching and learning. & $223.32^{* *}$ \\
I evaluate positively my experience of online teaching and learning. & $168.77^{* *}$ \\
I feel tired with online teaching and learning & $153.17^{* *}$ \\
I feel under stress with online teaching and learning & $132.3^{* *}$ \\
I feel fear with online teaching and learning & $167.98^{* *}$ \\
\hline
\end{tabular}

$* *$ Significant at $p<0.0001$ 
Table 7 Means and standard deviations of indicators regarding students' adaptation to online teaching and learning from the part of the students who would prefer only online teaching $(n=139)$, only face-to-face teaching $(n=692)$ and both face-to-face and online teaching $(n=1064)$ for next academic year

\begin{tabular}{lccc}
\hline & $\begin{array}{l}\text { I would prefer only } \\
\text { online teaching } \\
\text { Mean (SD) }\end{array}$ & $\begin{array}{l}\text { I would prefer only face } \\
\text { to face teaching } \\
\text { Mean (SD) }\end{array}$ & $\begin{array}{l}\text { I would prefer both online and } \\
\text { face-to-face teaching } \\
\text { Mean (SD) }\end{array}$ \\
\hline $\begin{array}{l}\text { I learn well with online } \\
\text { teaching and learning. }\end{array}$ & $4.04(1.01)$ & $2.16(1.01)$ & $3.06(1.09)$ \\
$\begin{array}{l}\text { I have adapted well to the } \\
\text { closure of my institution. }\end{array}$ & $4.06(1.06)$ & $2.42(1.04)$ & $3.24(1.09)$ \\
$\begin{array}{l}\text { I feel comfortable with online } \\
\text { teaching and learning. }\end{array}$ & $3.78(1.25)$ & $1.91(.93)$ & $3.81(1.13)$ \\
$\begin{array}{l}\text { I am dealing well with online } \\
\text { teaching and learning. }\end{array}$ & $4.01(1.06)$ & $2.13(1.07)$ & $3.17(1.04)$ \\
$\begin{array}{l}\text { My experience with online } \\
\text { teaching has been positive. }\end{array}$ & $3.98(1.04)$ & $2.45(1.04)$ & $3.91(1.09)$ \\
$\begin{array}{l}\text { I feel tired with online teaching } \\
\text { and learning. }\end{array}$ & $2.76(1.41)$ & $4.41(.88)$ & $3.79(1.17)$ \\
$\begin{array}{l}\text { I feel under stress with online } \\
\text { teaching and learning. }\end{array}$ & $2.68(1.44)$ & $4.30(0.94)$ & $3.56(1.2)$ \\
$\begin{array}{l}\text { I feel fear with online teaching } \\
\text { and learning. }\end{array}$ & $2.39(1.31)$ & $4.19(0.95)$ & \\
\hline
\end{tabular}

\section{Differences in perceptions of online assessment between students who adapted positively to the closure of their institution and those who did not}

Regarding the perceptions about online assessment, in general, students were not satisfied with it, as they felt it was more unfair, more difficult and more likely to lead to cheating. Considering the differences in perceptions about the online assessment of students who reported a positive or negative adaptation to online teaching and learning (Table 9), the former were more satisfied with online assessment, considering that it was more effective than when face-to-face. On the contrary, students who adapted negatively to online teaching and learning considered online assessment more unfair, more difficult and more likely to lead to cheating.

Table 8 Perceptions about online teaching: t-test for equality of means of independent samples by gender

\begin{tabular}{|c|c|c|c|}
\hline & $\begin{array}{l}\text { Male students } \\
M(S D) \\
\mathrm{N}=525\end{array}$ & $\begin{array}{l}\text { Female } \\
\text { students } \\
M(S D) \\
\mathrm{N}=1010\end{array}$ & $\begin{array}{l}t \\
(\text { d.f. })\end{array}$ \\
\hline I feel under stress in online teaching and learning. & $\begin{array}{c}3.76 \\
(1.24)\end{array}$ & $\begin{array}{c}3.97 \\
(1.14)\end{array}$ & $\begin{array}{l}-3.26 * * \\
(988,07)\end{array}$ \\
\hline I have adapted well to the closure of my institution. & $\begin{array}{c}2.87 \\
(1.21)\end{array}$ & $\begin{array}{c}3.08 \\
(1.17)\end{array}$ & $\begin{array}{c}-3.35 * * \\
(1533)\end{array}$ \\
\hline My experience of online teaching and learning. has been positive. & $\begin{array}{c}2.77 \\
(1.56)\end{array}$ & $\begin{array}{c}3.05 \\
(1.13)\end{array}$ & $\begin{array}{c}-4.58 * * \\
(1533)\end{array}$ \\
\hline I feel satisfied with online teaching and learning.. & $\begin{array}{c}2.37 \\
(1.25)\end{array}$ & $\begin{array}{c}2.55 \\
(1.24)\end{array}$ & $\begin{array}{c}-2.67 * * \\
(1533)\end{array}$ \\
\hline I learn well in online teaching and learning. & $\begin{array}{c}2.68 \\
(1.22)\end{array}$ & $\begin{array}{c}2.85 \\
(1.18)\end{array}$ & $\begin{array}{c}-2.61 * * \\
(1030,58)\end{array}$ \\
\hline
\end{tabular}

**Significant at $p<0.01$ 
Table 9 Perceptions about online assessment: t-test for equality of means of independent samples by adaptation to the closure of the institution

\begin{tabular}{|c|c|c|c|}
\hline & $\begin{array}{l}\text { Negative } \\
\text { adaptation } \\
M(S D) \\
\mathrm{N}=635\end{array}$ & $\begin{array}{l}\text { Positive } \\
\text { adaptation } \\
M(S D) \\
\mathrm{N}=629\end{array}$ & $\begin{array}{l}t \\
(d . f .)\end{array}$ \\
\hline I feel satisfied with online assessment. & $2.07(1.06)$ & $\begin{array}{l}3.22 \\
(1.16)\end{array}$ & $\begin{array}{l}-18.46^{* *} \\
(1249.15)\end{array}$ \\
\hline Online assessment is more unfair than face to face assessment. & $3.88(1.13)$ & $\begin{array}{l}3.26 \\
(1.12)\end{array}$ & $\begin{array}{l}9.75 * * \\
(1261)\end{array}$ \\
\hline Online assessment is more effective than face to face assessment. & $1.84(0.89)$ & $\begin{array}{l}2.49 \\
(0.1)\end{array}$ & $\begin{array}{l}-12.18 * * \\
(1242.70)\end{array}$ \\
\hline Online assessment is more difficult than face to face assessment. & $3.73(1.07)$ & $\begin{array}{l}3.31 \\
(1.06)\end{array}$ & $\begin{array}{l}7.08 * * \\
(1261)\end{array}$ \\
\hline $\begin{array}{l}\text { Online assessment is more likely to lead to cheating than face to face } \\
\text { assessment. }\end{array}$ & $3.97(1.09)$ & $\begin{array}{l}3.70 \\
(1.09)\end{array}$ & $\begin{array}{l}4.44 * * \\
(1261)\end{array}$ \\
\hline
\end{tabular}

** Significant at $p<0.0001$

When comparing students who were assessed in synchronous sessions and those who were assessed in asynchronous sessions (Table 10), the t-test for equality of means of independent samples by online assessment done synchronously or asynchronously showed significant differences between the two groups. Students who did online assessment in synchronous sessions were more satisfied and considered online assessment more effective than face-to-face assessment, than the students who did online assessment asynchronously $(p<0.001)$. Additionally, students in situation of asynchronous assessment also considered online assessment more difficult $(p<0.05)$.

Table 10 Perceptions about online assessment: t-test for equality of means of independent samples by synchronous and asynchronous assessment

\begin{tabular}{|c|c|c|c|}
\hline & $\begin{array}{l}\text { Asynchronous } \\
\text { assessment } \\
M(S D) \\
N=371\end{array}$ & $\begin{array}{l}\text { Synchronous } \\
\text { assessment } \\
M(S D) \\
N=928\end{array}$ & $\begin{array}{l}t \\
(d . f .)\end{array}$ \\
\hline I feel satisfied with online assessment. & $\begin{array}{c}2.40 \\
(1.24)\end{array}$ & $\begin{array}{c}2.71 \\
(1.22)\end{array}$ & $\begin{array}{r}-4.18 * * \\
(1297)\end{array}$ \\
\hline $\begin{array}{l}\text { Online assessment is more unfair than face-to-face } \\
\text { assessment. }\end{array}$ & $\begin{array}{c}3.67 \\
(1.20)\end{array}$ & $\begin{array}{c}3.58 \\
(1.16)\end{array}$ & $\begin{array}{c}1.25 \\
(1297)\end{array}$ \\
\hline $\begin{array}{l}\text { Online assessment is more effective than face-to-face } \\
\text { assessment. }\end{array}$ & $\begin{array}{c}2.02 \\
(0.98)\end{array}$ & $\begin{array}{c}2.19 \\
(1.00)\end{array}$ & $\begin{array}{l}-2.83 * * \\
(1297)\end{array}$ \\
\hline $\begin{array}{l}\text { Online assessment is more difficult than face-to-face } \\
\text { assessment. }\end{array}$ & $\begin{array}{l}3.65 \\
(1.1)\end{array}$ & $\begin{array}{c}3.5 \\
(1.06)\end{array}$ & $\begin{array}{r}2.17 * \\
(1297)\end{array}$ \\
\hline $\begin{array}{l}\text { Online assessment is more likely to lead to cheating than } \\
\text { face-to-face assessment. }\end{array}$ & $\begin{array}{c}3.83 \\
(1.08)\end{array}$ & $\begin{array}{c}3.84 \\
(1.10)\end{array}$ & $\begin{array}{c}-.26 \\
(1297)\end{array}$ \\
\hline
\end{tabular}

**Significant at $p<0.001$

$*$ Significant at $p<0.005$ 


\section{Discussion}

The rapid and sudden move from face-to-face to online teaching has marked the academic year of 2020 due to the spread of COVID-19 at a global scale. An unpredictable situation has altered the teaching and learning process drastically and has forced institutions, teachers and students to adopt adaptation strategies.

The present study sought to explore the factors that contribute to differentiate students who adapted well from students who found it difficult to adapt to the closure of their university. Existing literature suggests that there were diverse responses from students in terms of studying time (Aucejo et al., 2020) and from institutions which were forced to shift to remote teaching (Flores \& Gago, 2020; la Velle et al., 2020; Osman, 2020; Quezada et al., 2020). A positive adaptation of the students was directly associated with their beliefs in their competencies to follow online teaching successfully and to learn well in online environments. Therefore, self-regulated students showing autonomy in their learning process and higher levels of self-efficacy beliefs (Zuffianò et al., 2012) may have been better prepared to manage time and attention, and make the most of available resources (Zimmermann, 2011).

One of the research questions analysed whether there were differences in the adaptation to one's own learning process between students who had previous experience of online teaching and those who had not. Findings suggest that previous experience of online teaching and learning was related to a positive student adaptation to the closure of higher education institutions. In fact, findings revealed that students with previous experience of online teaching had significantly higher means in all positive indicators of learning than students without experience. The latter considered that online teaching and learning was more difficult, and they showed fear/anxiety, tiredness and stress. These students also had higher means in the items related to difficulties in concentrating and resisting external difficulties. Therefore, students who adapted well showed significantly lower means in items related to negative emotions, such as stress and tiredness. Conversely, students who adapted negatively reported difficulties in concentrating and referred to more negative feelings, such as stress and anxiety. The findings of the present study are also in line with earlier research which suggests that prior learning experiences were positively associated with students' evaluation of and satisfaction with online education (Wang et al., 2020). Results also add to empirical work which highlights the connection between students' readiness for digital learning and self-reported socio-emotions, such as less tension, overload, worries and social and emotional loneliness and more joy (Händel et al., 2020). These findings lend support to earlier research (Baloran, 2020; Rajab et al., 2020; Son et al., 2020) which points to increased levels of stress and anxiety, difficulties in concentrating and concerns with one's own health and academic performance. Moreover, because of the impact on students' emotions, findings from this study highlight the importance of developing self-regulatory and socio-emotional competencies during the academic trajectory to offer better conditions for learning and dealing with different learning environments. This corroborates earlier empirical work which also suggests the need to invest in students' socio-emotional competencies (Hadar et al., 2020). It is imperative for both teachers and higher education institutions to invest in the provision of opportunities for students to develop such competencies. In addition, it is crucial to promote students' agency in their own learning process with control over cognitive, motivational and behavioural aspects which are required in a successful adaptation to a diversity of learning situations (Bandura, 2006). Future research could investigate possible associations between students' degree of self-regulation and the level of self-efficacy beliefs and their capacity to adapt to new learning environments 
(Bandura, 2006), namely through learning diaries that enable a longitudinal analysis of selfregulation processes associated with perceived learning outcomes (Ferreira et al., 2015).

Findings from this study also point to the key role of teachers. The analysis of the data enabled the exploration of the research question regarding whether there were differences in perceptions about online teaching, the adaptation to the learning process, the difficulties encountered and the practices and motivations of teachers between students who had a positive adaptation to the closure of their institution and those who had not. Results showed the impact of teachers on a positive adaptation. Teacher support and availability, as well as the quality of the material they provided students with, were factors which differentiated the students who adapted well to online teaching. Conversely, students who did not adapt well to online teaching claimed less support from their teachers. These results suggest the importance of pedagogical practices and the quality of interactions, as teacher support is a key element for students' learning process (Morris, 2020). Results obtained have shown that, although, in general, the adaptation of higher education students was positive, there were students who did not adapt well and that the success of the adaptation process was also related to other contextual factors, beyond the support and the availability of teachers.

The third research question sought to explore the contextual factors that were more associated with a positive adaptation to learning and teaching online. Results point to issues of institutional responses to deal with the abrupt transition to online teaching, namely the external conditions and the access to the necessary technical resources, which may explain why some students adapted negatively and others positively.

Considering the double impact of personal and contextual factors, supported by the present research, issues such as story-based technology-supported learning environments that foster self-regulation strategies through explicit teaching (Ferreira et al., 2017) as well as programmes focusing on the development of specific socio-emotional competencies, such as self and social awareness, self-management, relationship skills and responsible decisionmaking (Pereira \& Marques-Pinto, 2018) may be considered in further research.

Results concerning the research question about the indicators that differentiated students who preferred online teaching, face-to-face teaching or blended learning for the next academic year revealed statistically significant lower means in negative indicators (feeling stressed or tired) in students who preferred online or blended methods. Inversely, these students had higher means in all positive indicators of adaptation (feeling comfortable, dealing well and perceiving the online experience as positive). Almost half of the students who did not have a positive adaptation mentioned that the possibility of having online teaching was a positive prospect for the next academic year. This finding is innovative with regard to other studies (e.g. Hill \& Fitzgerald, 2020), because even those who reported to have had a negative adaptation considered the possibility of online teaching and learning to be a positive alternative for the future. Most of the students who adapted positively mentioned they would prefer a hybrid format. This should be taken into consideration in rethinking teaching in future scenarios, including instructional material in an interactive online format with timely feedback and face-to-face collaborative practical lessons with teachers and peers.

Concerning the analysed differences as a function of gender in the adaptation to online teaching and learning, there were few significant differences between male and female students. Higher levels of perceived stress satisfaction and perception of academic success were reported by female students. However, differences between male and female students regarding their perception of online assessment were significant. Male students were less satisfied than female students with online assessment and considered it more unfair. 
The next two research questions, regarding students' perceptions about online assessment and the impact of the condition of being synchronous or asynchronous, led to the conclusion that remote assessment was seen as more unfair and more difficult than face-to-face assessment, but when conducted synchronously, it was considered more satisfactory than in an asynchronous manner. Cheating was also more associated with remote assessment by the participants in the study, which is in line with earlier work that identified academic dishonesty as the most frequently discussed challenge in higher education (Guangul et al., 2020). The diversity of assessment tools, the participation of students in the assessment process through peer and self-assessment, as well as issues related to monitoring students' work, are key aspects in the assessment process, and are particularly relevant in online environments (Gikandi et al., 2011). Rahim (2020) suggested a balance between summative and formative assessment in emergency remote teaching, since teachers should provide students with useful feedback regarding their achievement of stated learning objectives. Research has indicated that when students acknowledge the relevance of assessment, they use insights from it to improve their learning, performance and achievement (Flores et al., 2020). Similarly, the use of different assessment methods, students' participation and the meaning they attach to the assessment process are key variables in looking at its effectiveness (Pereira, Niklasson, \& Flores, 2017; Pereira, Flores, \& Barros, 2017; Pereira et al., in press).

This study is not without limitations. It is cross-sectional in nature; therefore, it would be interesting to investigate the variables studied here through experimental designs including objective data. Future studies could also consider investigating teaching methodologies, pedagogical interactions and assessment in online environments, considering both internal and external factors that may hinder or facilitate students' predispositions and motivations to learn, particularly in online environments. These are key aspects for higher education institutions to consider in (re)designing present and future teaching scenarios and in articulating a more coherent and systemic response to the challenges faced during and in the post-COVID-19 times. It would also be interesting for future studies to understand the role of group efficacy in collaborative learning online.

\section{Conclusions}

Overall, this study has shown that both personal and contextual factors seem to explain students' positive or negative adaptation to online teaching and learning as a result of the closure of higher education institutions. Institutional and pedagogical responses, individual self-regulatory and socio-emotional competencies and adequate resources are factors that led to more positive or negative student experiences of online teaching in times of COVID-19. As Carrillo and Flores (2020) suggest, there should be a comprehensive view of pedagogy in online education that integrates technology to support teaching and learning. Also needed is the investment in teachers and students' preparation for a more successful use of online environments for teaching and learning.

Considering the results regarding the positive impact of the previous experience of online learning and teaching, it is important to draw on students' experience of online teaching and learning during lockdown to revisit and improve existing practices of teaching and assessment. Teachers' pedagogical responses also need to be taken into 
consideration, as results concerning the impact of teachers on the positive adaptation of students suggest that pedagogical interaction and ways of organising teaching and learning activities along with processes of mentoring and monitoring of students' work, especially in an online environment, are of utmost importance.

\section{References}

Alves, R. F., Samorinha, C., \& Precioso, J. (2020). Knowledge, attitudes and preventive behaviors toward Covid19: A study among higher education students in Portugal. Journal of Health Research. Advance online publication. https://doi.org/10.1108/JHR-07-2020-0254

Aristovnik, A., Keržič, D., Ravšelj, D., Tomaževič, N., \& Umek, L. (2020). Impacts of the COVID-19 pandemic on life of higher education students: A global perspective. Sustainability. Advance online publication. https://doi.org/10.3390/su12208438

Aucejo, E., French, J., Araya, M., \& Zafar, B. (2020). The impact of Covid-19 on student experiences and expectations: Evidence from a survey. Journal of Public Economics. Advance online publication. https:/doi. org/10.1016/j.jpubeco.2020.104271

Baloran, E. (2020). Knowledge, attitudes, anxiety, and coping strategies of students during COVID-19 pandemic. Journal of Loss and Trauma, 25(8), 635-642. https://doi.org/10.1080/15325024.2020.1769300

Bandura, A. (2006). Toward a psychology of human agency. Perspectives on Psychological Science, 1(2), 164 180 https://doi.org/10.1111/2Fj.1745-6916.2006.00011.x

Bao, W. (2020). Covid 19 and online teaching in higher education. A case study of Peking University. Human Behavior \& Emerging Technologies, 2, 113-115. https://doi.org/10.1002/hbe2.191

Bisht, R. K., Jasola, S., \& Bisht, I. P. (2020). Acceptability and challenges of online higher education in the era of Covid-19. A study of students' perspective. Asian Education and Development Studies. Advance online publication. https://doi.org/10.1108/AEDS-05-2020-0119

Brady, A., \& Pradhan, D. (2020). Learning without borders: Asynchronous and distance learning in the age of Covid-19 and beyond. Ats Scholar. Advance online publication. https://doi.org/10.34197/atsscholar.20200046PS

Carrillo, C., \& Flores, M. A. (2020). COVID-19 and teacher education: a literature review of online teaching and learning practices. European Journal of Teacher Education, 43(4), 466-487. https://doi.org/10.1080/ 02619768.2020 .1821184

Chen, E., Kaczmarek, K., \& Ohyama, H. (2020). Student perceptions of distance learning strategies during Covid-19. Journal of Dental Education. Advance online publication. https://doi.org/10.1002/jdd.12339

Crawford, J., Butler-Henderson, K., Rudolph, J., Malkawi, B., Glowatz, M., Burton, R., et al. (2020). Covid-19: 20 countries' higher education intra-period digital pedagogy responses. Journal of Applied Learning \& Teaching, 3(1), 1-20. https://doi.org/10.37074/jalt.2020.3.1.7

Demuyakor, J. (2020). Coronavirus (Covid-19) and online learning in higher institutions of education: A survey of the perceptions of Ghanaian International Students in China. Online Journal of Communication and Media Technologies, 10(3), e202018. https://doi.org/10.29333/ojcmt/8286

Ferreira, P. C., Simão, A. M. V., \& da Silva, A. L. (2015). Does training in how to regulate one's learning affect how students report self-regulated learning in diary tasks? Metacognition and Learning, 10, $199-230$. https://doi.org/10.1007/s11409-014-9121-3

Ferreira, P. C., Simão, A. M. V., \& da Silva, A. L. (2017). How and with what accuracy do children report selfregulated learning in contemporary EFL instructional settings? European Journal of Psychology of Education, 32, 589-615. https://doi.org/10.1007/s10212-016-0313-x

Flores, M. A., \& Gago, M. (2020). Teacher education in times of COVID-19 pandemic in Portugal: national, institutional and pedagogical responses. Journal of Education for Teaching, 46(4), 507-516. https://doi.org/ 10.1080/02607476.2020.1799709

Flores, M. A., Brown, G., Pereira, D., Coutinho, C., Santos, P., \& Pinheiro, C. (2020). Portuguese university students' conceptions of assessment: taking responsibility for achievement. Higher Education, 79, 377-394. https://doi.org/10.1007/s10734-019-00415-2

Flores, M. A., Machado, E. A., Alves, P., \& Vieira, D. A. (2021). Ensinar em tempos de COVID-19: um estudo com professores dos ensinos básico e secundário em Portugal, Revista Portuguesa de Educação, 34(1), 5-27. https://doi.org/10.21814/rpe.21108 
Fuller, R., Joynes, V., Cooper, J., Boursicot, K., \& Roberts, T. (2020). Could Covid-19 be our 'There is no alternative' (TINA) opportunity to enhance assessment? Medical Teacher, 42(7), 781-786. https://doi.org/ 10.1080/0142159X.2020.1779206

García-Peñalvo, F., Corell, A., Abella-García, V., \& Grande, M. (2020). Online assessment in higher education in the time of Covid-19. Education in The Knowledge Society, 21, 1-26. https://doi.org/10.14201/eks.23013

Gikandi, J. W., Morrow, D., \& Davis, N. E. (2011). Online formative assessment in higher education: A review of the literature. Computers \& Education, 4(57), 2333-2351. https://doi.org/10.1016/j.compedu.2011.06. 004

Gonçalves, S. P., Sousa, M. J., \& Pereira, F. S. (2020). Distance learning perceptions from higher education students — The case of Portugal. Education in Science, 10(12), 374. https://doi.org/10.3390/ educsci10120374

Gonzalez, T., de la Rubia, M. A., Hincz, K. P., Comas-Lopez, M., Subirats, L., \& Fort, S. (2020). Influence of Covid-19 confinement on students' performance in higher education. PLoS One, 15(10), e0239490. https:// doi.org/10.1371/journal.pone.0239490

Guangul, F. M., Suhail, A. H., Khalit, M. I., \& Khidhir, B. A. (2020). Challenges of remote assessment in higher education in the context of Covid-19: A case study of Middle East College. Educational Assessment, Evaluation and Accountability. Advance online publication. https://doi.org/10.1007/s11092-020-09340-w

Hadar, L., Ergas, O., Alpert, B., \& Ariav, T. (2020). Rethinking teacher education in a VUCA world: Student teachers' social-emotional competencies during the Covid-19 crisis. European Journal of Teacher Education, 43(4), 573-586. https://doi.org/10.1080/02619768.2020.1807513

Händel, M., Stephan, M., Gläser-Zikuda, M., Kopp, B., Bedenlier, S., \& Ziegler, A. (2020). Digital readiness and its effects on higher education students' socio-emotional perceptions in the context of the Covid-19 pandemic. PsyArXiv. Advance online publication. https://doi.org/10.31234/osf.io/b9pg7

Harley, J., Lou, N., Liu, Y., Cutumisu, M., Daniels, L., Leighton, J., et al. (2020). University students' negative emotions in a computer-based examination: The roles of trait test-emotion, prior test-taking methods and gender. Assessment \& Evaluation in Higher Education, Advance online publication. https://doi.org/10.1080/ 02602938.2020 .1836123

Hill, K., \& Fitzgerald, R. (2020). Student perspectives on the impact of Covid-19 on learning. AISHE-J, 12(2), 19 retrieved from: http://ojs.aishe.org/index.php/aishe-j/article/view/459

la Velle, L., Newman, S., Montgomery, C., \& Hyatt, D. (2020). Initial teacher education in England and the Covid-19 pandemic: Challenges and opportunities. Journal of Education for Teaching, 46(4), 596-608. https://doi.org/10.1080/02607476.2020.1803051

Levatti, H. (2020). A strategy to face the impact of Covid-19 and technology disruption on higher education in the 2020-2025 lustrum, retrieved from: https://www.researchgate.net/publication/342437630_2020_A_ strategy_to_face_the_impact_of_Covid-19_and_technology_disruption_on_higher_education_in_the_ 2020-2025_lustrum

MCTES. (2020). Nota de Esclarecimento do Gabinete do Ministro da Ciência, Tecnologia e Ensino Superior de 13 março. Ministério da Ciência, Tecnologia e Ensino Superior retrieved from https://www.sec-geral.mec.pt/ noticia/nota-de-esclarecimento-do-gabinete-do-ministro-da-ciencia-tecnologia-e-ensino-superior

Metcalfe, A. (2020). Visualizing the Covid-19 pandemic response in Canadian higher education: An extended photo essay. Studies in Higher Education. Advance online publication. https://doi.org/10.1080/03075079. 2020.1843151

Morris, T. H. (2020). Creativity through self-directed learning: three distinct dimensions of teacher support. International Journal of Lifelong Education, 39(2), 168-178. https://doi.org/10.1080/02601370.2020. 1727577

OECD. (2020). Education responses to covid-19: Embracing digital learning and online collaboration. Retrieved from https://read.oecd-ilibrary.org/view/?ref=120_120544-8ksud7oaj2\&title=Education responses_to_Covid19_Embracing_digital_learning_and_online_collaboration

Osman, M. (2020). Global impact of Covid-19 on education systems: The emergency remote teaching at Sultan Qaboos University. Journal of Education for Teaching. Advance online publication. https://doi.org/10.1080/ 02607476.2020 .1802583

Pereira, D.; Cadime, I.; Brown, G. \& Flores, M. A. (2021) How do undergraduates perceive the use of assessment? A study in higher education, European Journal of Higher Education, https://doi.org/10.1080/ 21568235.2020.1871393

Pereira, N. S., \& Marques-Pinto, A. (2018). Development of a social and emotional learning program using educational dance: A participatory approach aimed at middle school students. Studies in Educational Evaluation, 59, 52-57. https://doi.org/10.1016/j.stueduc.2018.03.003

Pereira, D., Flores, M. A., \& Barros, A. (2017). Perceptions of Portuguese undergraduate students about assessment: A study in five public universities. Educational Studies, 43, 442-463. 
Pereira, D., Niklasson, L., \& Flores, M. A. (2017). Students' perceptions of assessment: A comparative analysis between Portugal and Sweden. Higher Education, 73, 153-173.

Quezada, R., Talbot, C., \& Quezada-Parker, K. (2020). From bricks and mortar to remote teaching: A teacher education program's response to Covid-19. Journal of Education for Teaching, 46(4), 472-483. https://doi. org/10.1080/02607476.2020.1801330

Rahim, A. F. A. (2020). Guidelines for online assessment in emergency remote teaching during the Covid-19 pandemic. Education in Medical Journal, 12(2), 59-68. https://doi.org/10.21315/eimj2020.12.2.6

Rajab, M. H., Gazal, A. M., \& Alkattan, K. (2020). Challenges to online medical education during the Covid-19 pandemic. Cureus, 12(7), e8966. https://doi.org/10.7759/cureus.8966

Shahzad, A., Hassan, R., Aremu, A. Y., Hussain, A., \& Lodhi, R. (2020). Effects of Covid-19 in E-learning on higher education institution students: The group comparison between male and female. Quality \& Quantity. Advance online publication. https://doi.org/10.1007/s11135-020-01028-Z

Son, C., Hegde, S., Smith, A., Wang, X., \& Sasangohar, F. (2020). Effects of Covid-19 on college students' mental health in the United States: Interview survey study. Journal of Medical Internet Research, 22(9), e21279. https://doi.org/10.2196/21279

Vicente, P. N., Lucas, M., Carlos, V., \& Bem-Haja, P. (2020). Higher education in a material world: Constraints to digital innovation in Portuguese universities and polytechnic institutes. Education and Information Technologies. Advance online publication. https://doi.org/10.1007/s10639-020-10258-5

Wang, C., Xie, A., Wang, W., \& Wu, H. (2020). Association between medical students' prior experiences and perceptions of formal online education developed in response to Covid-19: A cross-sectional study in China. BMJ Open, Advance online publication. https://doi.org/10.1136/bmjopen-2020-041886

Xavier, B., Camarneiro, A. P., Loureiro, L., Menino, E., Cunha-Oliveira, A., \& Monteiro, A. P. (2020). Impacto da COVID-19 nas dinâmicas sociofamiliares e académicas dos estudantes de enfermagem em Portugal. Revista de Enfermagem, 4, 1-9. https://doi.org/10.12707/RV20104

Yang, R. (2020). China's higher education during the Covid-19 pandemic: Some preliminary observations. Higher Education Research and Development, 39(7), 1317-1321. https://doi.org/10.1080/07294360.2020. 1824212

Zhang, W., Wang, Y., Yang, L., \& Wang, C. (2020). Suspending classes without stopping learning: China's education emergency management policy in the Covid-19 outbreak. Journal of Risk and Financial Management, 13(3), 55. https://doi.org/10.3390/jrfm13030055

Zimmermann, B. (2011). Motivational sources and outcomes of self-regulated learning and performance. In B. Zimmerman \& D. Schunk (Eds.), Handbook of self-regulation and performance (pp. 49-59). Taylor \& Francis.

Zuffianò, A., Alessandrini, G., Gerbino, M., Kanacri, B. P. L., DiGiunta, L., Milioni, M., et al. (2012). Academic achievement: The unique contribution of self-efficacy beliefs in self-regulated learning beyond intelligence, personality traits, and self-esteem. Learning and Individual Differences, 23, 158-162. https://doi.org/10. 1016/j.lindif.2012.07.010

Publisher's note Springer Nature remains neutral with regard to jurisdictional claims in published maps and institutional affiliations.

\title{
Affiliations
}

\section{Maria Assunção Flores ${ }^{1}$ - Alexandra Barros ${ }^{2} \cdot$ Ana Margarida Veiga Simão $^{2}$ • Diana Pereira $^{1}$ - Paulo Flores ${ }^{3} \cdot$ Eva Fernandes $^{1} \cdot$ Luís Costa $^{1} \cdot$ Paula Costa Ferreira $^{2}$}

\author{
Alexandra Barros \\ afbarros@psicologia.ulisboa.pt \\ Ana Margarida Veiga Simão \\ amsimao@psicologia.ulisboa.pt \\ Diana Pereira \\ dianapereira@ie.uminho.pt
}


Paulo Flores

pflores@dem.uminho.pt

Eva Fernandes

evalopesfernandes@ie.uminho.pt

Luís Costa

luiscg.costa@hotmail.com

Paula Costa Ferreira

paula.costa.ferreira@gmail.com

Research Centre on Child Studies. Institute of Education, University of Minho, Braga, Portugal

2 CICPSI, Faculdade de Psicologia, Universidade de Lisboa, Lisboa, Portugal

3 CMEMS-UMinho, Department of Mechanical Engineering, University of Minho, Campus de Azurém, Guimarães 4804-533, Braga, Portugal 